\title{
TEKNIK PARENTING DAN PENGASUHAN ANAK STUDI DESKRIPTIF PENERAPAN TEKNIK PARENTING DI RUMAH PARENTING YAYASAN CAHAYA INSAN PRATAMA BANDUNG
}

\author{
Oleh: \\ Mutiara Suci Erlanti, Nandang Mulyana, \& .Hery Wibowo \\ Email: Mutiara_erlanti@yahoo.com; Nandangmulyana@yahoo.com; Hery_fortune@yahoo.com
}

\begin{abstract}
Parenting knoledge should be owned by a parent in order to better parenting and support the growth and development of children. However, in reality not all parents have sufficient knowledge and skills regarding parenting. The lack of knowledge and skills of parents about parenting can lead to abuse in children. Parenting by parents affected by several factors such as social and physical environment where the family lived, the economic status of parents, and the model of care that parents previously obtained.

Parents can broaden their knowledge and skills in parenting byi Parenting Education programs. Parenting Education (Pendidkan Parenting) is an education that seeks to improve or facilitate parental behavior that will affect the positive results in the development of their children. Parenting education explaining various teaching and support programs that focus on skills, feelings, and the task of being a parent. Parenting education is usually provided by an institution of formal and nonformal education with the different focus on the target, the types, methods of delivering parenting education.

Application of parenting techniques can be a method or a way to help parents better able to care for their children. Parenting techniques are include people who work in response to the actions of children and people who happen independent of the actions of children in an attempt to facilitate behavior socially acceptable. When linked with the concept of social work, institutions that provide parenting education services is a source system for clients who have concerns about child care.
\end{abstract}

Based on the previous translation, lack of knowledge and skills of parents about parenting can lead to abuse in children can be prevented and minimized as well as meeting the needs of children can be met when parents gain additional knowledge and parenting skills through parenting education program so that parents can apply a right parenting technique.

Keywords: Parenting knowledge, Parenting knowledge, Parenting Technique

Abstrak

Pengetahuan pengasuhan anak sebaiknya dimiliki oleh orang tua agar dapat mengasuh anak lebih baik dan menunjang pertumbuhan dan perkembangan anak. Namun, pada kenyataanya tidak semua orang tua memiliki pengetahuan dan keterampilan yang memadai mengenai pengasuhan anak. Minimnya pengetahuan dan keterampilan orang tua mengenai pengasuhan dapat menimbulkan perlakuan salah pada anak. Pengasuhan oleh orang tua dipengaruhi oleh beberapa faktor seperti 
lingkungan sosial dan fisik tempat dimana keluarga itu tinggal, status ekonomi orang tua, dan model pengasuhan yang didapatkan orang tua sebelumnya.

Orang tua dapat memperluas pengetahuan dan keterampilan dalam pengasuhan anak memlaui program-program Parenting Education. Parenting Education (Pendidkan Parenting) adalah pendidikan yang berupaya untuk meningkatkan atau memfasilitasi perilaku orang tua yang akan mempengaruhi hasil positif perkembangan pada anak-anak mereka). Parenting education menjelaskan berbagai program pengajaran dan dukungan yang fokus pada keterampilan, perasaan, dan tugas menjadi orangtua). Parenting education ini biasanya diberikan oleh sebuah lembaga pendidikan formal dan non formal dengan fokus target, jenis-jenis, metode-metode penyampaian parenting education yang berbeda-beda.

Penerapan Teknik parenting dapat menjadi metode atau cara untuk membantu orang tua dapat mengasuh anaknya lebih baik. Teknik Parenting merupakan mencakup orang-orang yang bekerja dalam menanggapi tindakan anak dan orang-orang yang terjadi independen dari tindakan anak dalam upaya untuk memfasilitasi perilaku yang dapat diterima secara sosial. Apabila dikaitkan dengan konsep pekerjaan sosial, lembaga yang memberikan pelayanan parenting education merupakan sistem sumber bagi klien yang memiliki masalah mengenai pengasuhan anak.

Berdasarkan penjabaran sebelumnya, kurangnya pengetahuan dan keterampilan orang tua mengenai pengasuhan dapat menimbulkan perlakuan salah pada anak dapat dicegah dan diminimalisir serta pemenuhan kebutuhan pada anak dapat terpenuhi apabila orang tua mendapatkan penambahan pengetahuan dan keterampilan pengasuhan melalui program parenting education sehingga orang tua dapat menerapkan teknik atau cara mengasuh anak yang benar.

Kata Kunci : Pengetahuan pengasuhan, pendidikan parenting, teknik parenting

\section{PENDAHULUAN}

\section{Pengetahuan dan Keterampilan pengasuhan anak}

Pengasuhan merupakan suatu aspek penting dalam membentuk perkembangan diri anak. Orang tua tentu memerlukan pengetahuan dan keterampilan yang memadai agar dapat memberikan pengasuhan yang benar bagi anak. Pengetahuan pengasuhan meliputi memahami cara merawat anak-anak, bagaimana anak-anak mengembangkan, dan peran yang beragam orang tua bermain dalam kehidupan anak-anak. Pengetahuan pengasuhan termasuk memahami berbagai pendekatan yang tepat untuk memenuhi kebutuhan fisik dan biologis dan sosioemosional dan kognitif anak-anak ketika mereka berkembang (Goodnow \& Collins, 1990 dalam William\&Lerner:2006:915).
Orang tua biasanya kategorinya sekutu orangorang yang paling konsisten dan peduli dalam kehidupan anak-anak mereka. Jika orang tua disediakan dengan pengetahuan, keterampilan, dan dukungan, mereka dapat merespon lebih positif dan efektif untuk anak-anak mereka. Kebutuhan emosional dan fisik orang tua sendiri harus dipenuhi jika mereka ingin membesarkan anak-anak secara optimal. Manusia tampaknya memiliki sejumlah pengetahuan intuitif tentang pengasuhan (Papousek \& Papousek, 2002 dalam William\&Lerner:2006:919 ), dan manusia juga memperoleh pengetahuan tentang apa artinya untuk orang tua dengan hidup dalam suatu budaya: Generasi, sosial, dan media gambar orangtua, anak-anak, dan keluarga hidup diwariskan atau siap memainkan peran penting dalam membantu orang merumuskan kognisi orangtua mereka dan panduan praktik pengasuhan mereka (Holden \& Buck, 2002; 
Sigel \& McGillicuddy- De Lisi, 2002 dalam William\&Lerner:2006:919).

Pengetahuan dan keterampilan orang tua dalam mengasuh anak diterapkan menjadi suatu pola asuh. Menurut Manurung (1995:53 dalam Agustiawati:2014), beberapa faktor yang mempengaruhi dalam pola pengasuhan orang tua adalah :

1. Latar belakang pola pengasuhan orang tua

Maksudnya para orang tua belajar dari metode pola pengasuhan yang pernah didapat dari orang tua mereka sendiri.

2. Tingkat pendidikan orang tua

Orang tua yang memiliki tingkat pendidikan tinggi berbeda pola pengasuhannya dengan orang tua yang hanya memiliki tingkat pendidikan yang rendah.

3. Status ekonomi serta pekerjaan orang tua Orang tua yang cenderung sibuk dalam urusan pekerjaannya terkadang menjadi kurang memperhatikan keadaan anakanaknya. Keadaan ini mengakibatkan fungsi atau peran menjadi "orang tua" diserahkan kepada pembantu, yang pada akhirnya pola pengasuhan yang diterapkanpun sesuai dengan pengasuhan yang diterapkan oleh pembantu.

Pengetahuan pengasuhan anak sebaiknya dimiliki oleh orang tua agar dapat mengasuh anak lebih baik dan menunjang pertumbuhan dan perkembangan anak. Namun, pada kenyataanya tidak semua orang tua memiliki pengetahuan dan keterampilan yang memadai mengenai pengasuhan anak. Minimnya pengetahuan dan keterampilan orang tua mengenai pengasuhan dapat menimbulkan perlakuan salah pada anak. Perlakuan Salah terhadap Anak adalah setiap tindakan terhadap anak, termasuk menempatkan anak dalam situasi yang dapat menyebabkan dampak buruk terhadap kesejahteraan, keselamatan, martabat dan perkembangan anak (Perda
No.10 2012 tentang Penyelenggaraan Perlindungan Anak).

Apabila ditinjau dari perspektif Human Behavior Social Environment, perkembangan diri seorang anak dipengaruhi oleh faktor lingkungan baik internal maupun eksternal. Anak menerima stimulus-stimulus dari lingkungan dan meresponnya menjadi suatu perilaku. Cara mengasuh tersebut diperoleh orang tua dari keyakinan (beliefs) dan pengalaman masa kecilnya . Selain itu, cara mengasuh anak yang diterapkan oleh orang tua berpotensi akan diamati dan ditiru oleh anaknya untuk mengasuh anaknya kelak.

\section{PEMBAHASAN}

\section{Parenting Education bagi orang tua}

Orang tua dapat memperluas pengetahuan dan keterampilan dalam pengasuhan anak memlaui program-program Parenting Education. Parenting Education (Pendidkan Parenting) adalah pendidikan yang berupaya untuk meningkatkan atau memfasilitasi perilaku orang tua yang akan mempengaruhi hasil positif perkembangan pada anak-anak mereka (Bornstein Vol IV:2002:434). Parenting education menjelaskan berbagai program pengajaran dan dukungan yang fokus pada keterampilan, perasaan, dan tugas menjadi orangtua (Einzig, 1996, hal. 222 dalam Bornstein Vol IV:2002:391). Parenting Education memiliki beberapa jenis berdasarkan poulasi targetnya, yaitu: Parenting education untuk semua orang tua, orang tua baru yang memiliki resiko, orang tua dengan pendapatan rendah, orang tua dengan pendidikan rendah, orang tua melakukan perlakuan salah dan penelantaran anak, pencegahan kekerasan pada anak-anak dengan Remaja disabilitas ( Bornstein Vol.5:2002:392).

Selanjutnya, jenis perenting education berfokus pada orang tua yaitu: pengetahuan, keterampilan, dan kemampuan parenting. Akademik, Ekonomi, defisiensi diri, 
Interpersonal, keluarga berencana, fokus kesehatan anak, perilaku sosioemosional, kognitif. Kualitas interaksi orang tua-anak, komunikasi perlakuan salah dan penelantaran serta Fungsi Keluarga fungsi ekonomi.Parenting education ini biasanya diberikan oleh sebuah lembaga pendidikan formal dan non formal dengan fokus target, jenis-jenis, metode-metode penyampaian parenting education yang berbeda-beda. Metode penyampaian parenting education termasuk buku pegangan dan manual; televisi, video, dan seri audio; kelas pengasuhan dan perkembangan anak berbasis kelompok, program kunjungan rumah; dan kombinasi di atas. Pendidikan Parenting dapat dirancang sebagai program akses universal untuk semua orang tua atau ditargetkan untuk orang tua yang diindentifikasi memiliki faktor risiko (Bornstein Vol IV:2002:392).

$\begin{array}{lll}\begin{array}{l}\text { Penerapan } \\ \text { pengasuhan }\end{array} & \text { Teknik Parenting dalam }\end{array}$

Pengasuhan dapat didefinisikan sebagai kegiatan yang memiliki tujuan agar dapat membuat anak bertahan menghadapi tantangan dari lingkungan serta dapat berkembang. Potensi anak dapat dikembangkan melalui serangkaian stimulus psikososial dari orang tua dan lingkungan (Hoghoughi, 2004).

Selanjutnya Brooks (2001) menjabarkan beberapa tujuan dari pengasuhan yaitu:

1. Menjamin kesehatan fisik (gizi dan kesehatan) dan kelangsungan hidup anak

2. Menyiapkan agar anak menjadi orang dewasa yang mandiri dan bertanggung jawab baik secara ekonomi, sosial dan moral.

3. Mendorong perilaku individu yang positif, termasuk cara penyesuaian diri, kemampuan intelektual, dan kemampuan berinteraksi sosial dengan orang lain agar dapat bertanggung jawab dan bermanfaat bagi lingkungan sekitar.

Teknik Parenting mencakup orang-orang yang bekerja dalam menanggapi tindakan anak dan orang-orang yang terjadi independen dari tindakan anak dalam upaya untuk memfasilitasi perilaku yang dapat diterima secara sosial.

Teknik Parenting yang dikemukakan Grusec ( dalam Bornstein:2002:154) yaitu : 1.) Disiplin; 2) Monitoring atau pemantauan;3)Rewardatau penghargaan; 4) Rutinitas Sehari-hari ;5) Prearming

Dampak Pengasuhan bagi Perkembangan Anak

Orang tua sebagai figur yang memegang peran penting dalam proses pengasuhan dituntut untuk terus mendukung dalam memelihara pertumbuhan anak tidak hanya secara fisik namun yang terpenting juga membentuk kelekatan emosional dan ikatan psikologis dengan anak (Brooks, 2001 dalam Malaila). Pengasuhan yang dilakukan oleh orang tua terhadap anak dapat berdampak pada perkembangan sang anak baik positif maupun negatif tergantung kepada bagaimana cara atau tehnik pengasuhan yang diterapkan kepada anak tepat atau tidak. Dampak positif dari pengasuhan bagi perkembangan anak:

Orang tua bertanggung jawab untuk berkontribusi secara substansial untuk pengembangan karakter etika dan kompetensi pada anak-anak mereka melalui upaya sosialisasi mereka (Baumrind, 1998 dalam Bornstein:2002:12). Perspektif anak-anak membentuk pemahaman mereka tentang upaya sosialisasi orang tua, tetapi perspektif mereka sangat dipengaruhi oleh perspektif orang tua mereka, yang didasarkan pada konteks budaya tertentu dan dipakai dalam perilaku orang dewasa.

\section{- Karakter}

Bagaimana mungkin orang tua memberikan kontribusi pada pengembangan karakter berbudi luhur pada anak-anak mereka? Wilson (1993 dalam Bornstein:2002:12) berpendapat bahwa anak-anak lahir dengan sentimen moral keadilan, tugas, simpati, dan pengendalian diri. Namun, mereka juga lahir egosentris, membutuhkan budidaya sentimen moral mereka dengan mensosialisasikan agen. 
Sentimen moral anak dibudidayakan paling efektif oleh pengasuh yang memiliki tujuan yang jelas, menegakkan arahan mereka, dan menyampaikan pesan mereka sederhana, tegas, dan konsisten.

\section{- $\quad$ Kompetensi}

Kompetensi adalah fungsi manusia yang efektif dalam pencapaian keinginan dan tujuan dihargai. Tujuan yang dinilai dalam budaya adalah mereka yang memungkinkan individu untuk mengejar tujuan pribadi mereka dalam batasan yang dikenakan oleh umum dan dengan jaringan sosial mereka (Bornstein:2002:14).

Perkembangan kompetensi anak adalah produk dari interaksi yang semakin kompleks dari anak berkembang dengan sosialisasi orang dewasa-terutama orang tua yang, selama tahun-tahun awal anak, memiliki kekuatan untuk mengendalikan interaksi ini (Bornstein:2002:15).

Pengasuhan yang dilakukan orang tua pun dapat berdampak negatif bagi anak. Bell (1968 dalam Bornestein:147) berpendapat bahwa banyak hubungan didirikan antara orangtua dan anak hasil perilaku dapat dengan mudah dijelaskan dalam hal efek anak-anak pada perilaku orang tua mereka sebagai sebaliknya. Dengan demikian korelasi antara hukuman koersif dan agresi dapat menunjukkan bahwa kekuatan orangtua pernyataan menghasilkan agresi pada anak-anak, atau anak-anak yang agresif menimbulkan disiplin yang kuat dari orang tua mereka, karena itulah satu-satunya intervensi yang mereka akan merespon.

Menurut Straus (1991,1994 dalam Bornstein:72), pemodelan orangtua dan kemarahan anak yang dihasilkan dari menggabungkan penyalahgunaan tersebut sebagai mekanisme kausal untuk mendorong perilaku agresif anak di masa depan. Dari perspektif sosial interaksional, teknik pengasuhan kasar, seperti memukul dan mengancam, cenderung sukses dalam jangka pendek dalam mengakhiri perilaku negatif anak. Hal ini meningkatkan kemungkinan bahwa orang tua akan menggunakan praktek- praktek yang kasar di masa depan. Namun, jika anak terus menerus atau meningkat, orang tua ini cenderung untuk mundur dan menghentikan pertukaran. Kompleksitas ini sebagian besar diabaikan oleh teori yang menyatakan bahwa hukuman fisik yang keras dan salah adalah penyebab langsung untuk agresi anak.

Penting bagi orang tua menggunakan pola pengasuhan yang tepat, sebab cara orang tua mengasuh anak akan sangat berhubungan dengan bagaimana perasaan anak tentang dirinya dan bagaimana anak berelasi dengan orang lain. ( Martin\&Colbert,1997 dalam Malaila). Sehingga, orang tua memerlukan pemahaman dan keterampilan mengenai penerapan teknik parenting dalam pengasuhan anak.

Teknik didefinisikan sebagai sebuah pengetahuan, cara, dan metode. Sedangkan, Parenting merupakan serangkaian interaksi berkelanjutan antara orang tua dan anak, yaitu proses yang menyebabkan perubahan kedua belah pihak. Menurut definisi, proses ini melibatkan proses melahirkan, melindungi, mengasuh, dan membimbing anak-anak. (Martin \& Colbert:1997).

Teknik Parenting merupakan mencakup orang-orang yang bekerja dalam menanggapi tindakan anak dan orang-orang yang terjadi independen dari tindakan anak dalam upaya untuk memfasilitasi perilaku yang dapat diterima secara sosial. (Grusec dalam Bornstein:2002:154)

Selanjutnya

(O’Connor\&Scott:2007) mengemukakan dampak pengasuhan terhadap perkembangan anak:

\section{Agresifitas}

Kualitas hubungan orangtua-anak dikaitkan dengan perilaku agresif dan kenakalan merupakan salah satu temuan yang paling banyak dilaporkan dalam literatur. Agresi dan kenakalan telah didefinisikan dalam berbagai cara, termasuk tindakan antisosial selama periode pengamatan; laporan guru yang 
agresif, perilaku mengganggu dalam laporan sekolah dan orang tua dari perilaku yang sama di rumah; catatan kriminalitas polisi; dan rekan melaporkan bahwa anak terlibat perkelahian atau menjadi (bully) pengganggu. Masingmasing definisi yang agresi atau istilah yang lebih umum 'eksternalisasi' perilaku berbeda, tapi ada sedikit keraguan bahwa setiap berhubungan dengan kualitas hubungan orangtua-anak (O’Connor\&Scott:2007) .

2. Depresi, kecemasan dan masalah 'internalisasi'

Bukti yang mendukung hubungan antara kualitas hubungan orangtua-anak dan depresi, kecemasan dan 'internalisasi' masalah lain (seperti keluhan somatik dan penarikan sosial) hampir sama kuat dan sama kuat seperti yang ditemukan untuk hasil eksternalisasi (O’Connor\&Scott:2007). Sama seperti dengan gejala eksternalisasi, ada bukti bahwa variasi individu dalam internalisasi gejala tidak secara khusus terkait dengan dimensi tunggal dari hubungan orangtua-anak. Kehangatan dan konflik keduanya terkait dengan depresi dan kecemasan; Namun, pengaruh dari strategi pengendalian umumnya ditemukan jauh lebih lemah. (O’Connor\&Scott:2007).

\section{Hasil kognitif dan pendidikan}

Beberapa teori kognitif (Rogoff dan Lave, 1984) telah mengusulkan bahwa hubungan orangtua-anak adalah konteks lingkungan penting yang penataan atau 'scaffolding' kemampuan kognitif muncul anak berlangsung. Orang tua mereka yang sensitif disetel untuk kemampuan kognitif anak dapat diharapkan untuk menyediakan lingkungan yang optimal bagi anak untuk belajar, yang dapat lebih didorong oleh motivasi anak sendiri. Pada anak yang lebih tua dan remaja, orang tua juga berpikir untuk membentuk aspirasi dan motivasi dengan bertindak sebagai model peran, memberikan dan memilih peluang bagi anak-anak, dan menetapkan harapan dan definisi yang sukses (Mortimer dan Kumka, 1982;. Bell et al, 1996 ; Gutman dan Eccles, 1999;. Jodl et al, 2001 dalam O’Connor\&Scott:2007).
4. Hubungan kompetensi sosial dan teman sebaya

Hubungan antara hubungan orangtua dan rekan diyakini dimediasi oleh kognisi sosial dan strategi perilaku belajar dari berinteraksi dengan orang tua. Pendekatan terkait mengusulkan bahwa kapasitas sosial-kognitif, seperti pemahaman emosional, perspektif taking dan regulasi emosional, yang dikembangkan dalam konteks hubungan awal orangtua-anak dan dilakukan ke depan untuk hubungan sosial kemudian, termasuk mereka dengan teman sebaya (Parke et al. 1989; Dekovic dan Janssens, 1992; Dunn, 1992; Carson dan Parke, 1996 dalam (O’Connor\&Scott:2007) ).

5. Harga diri dan identitas

Salah satu bidang lebih lanjut dari pembangunan sosial-psikologis yang telah mendapat perhatian dalam literatur orangtua dapat digambarkan sebagai harga diri dan identitas. Hubungan orangtua-anak akan memengaruhi apa yang beberapa peneliti sebut sebagai 'self-system' (misalnya Cicchetti, 1988) telah menjadi fokus khusus dari teori attachment. Internalisasi anak-anak dari pengalaman lampiran dipandang sebagai membentuk cara mereka melihat orang lain dan mengharapkan orang lain untuk bersikap terhadap mereka (O’Connor\&Scott:2007).

Teknik Parenting yang dikemukakan Grusec ( dalam Bornstein:2002:154) yaitu :

\section{Disiplin}

Banyak kepentingan dalam disiplin telah di kontras antara daya tegas atau teknik hukuman dan penalaran. Baru-baru ini telah difokuskan pada mediator, atau peristiwa yang terjadi sebagai akibat dari teknik pengasuhan dan bahwa, pada gilirannya, berdampak pada tindakan anak-anak. Krevans dan Gibbs (1996 dalam Bornstein:2002), misalnya, mencatat bahwa hubungan antara bentuk penalaran yang mengarahkan anak-anak untuk mempertimbangkan bagaimana perilaku mereka mempengaruhi orang lain dan 
meningkatkan prososial menanggapi adalah empati anak yang lebih besar.

\section{Monitoring atau Pemantauan}

Banyak penelitian telah menunjukkan bahwa orang tua menunjukkan pengetahuan tentang kegiatan dan keberadaan anak mereka adalah sukses dalam mempromosikan perilaku anak yang positif. Sekali lagi, Patterson dan rekanrekannya (antara lain) telah menunjukkan hubungan antara kurangnya pengetahuan orang tua dan perilaku antisosial. Agaknya, monitoring memungkinkan orang tua untuk menerapkan penguatan dan hukuman kontinjensi yang tepat serta untuk melindungi anak-anak mereka dari pengaruh-pengaruh negatif dari kelompok sebaya yang menyimpang.

\section{Reward atau Imbalan}

Rewarding artinya memberikan sesuatu yang menyenangkan atau ingin anak ketika ia berperilaku dalam cara yang diinginkan, sehingga perilaku diulang dan menjadi kebiasaan. Sebuah hadiah, hanya didefinisikan, adalah sesuatu yang anak Anda ingin. Dalam model ini, mereka dikategorikan sebagai Imbalan dasar dan Imbalan dasar. Imbalan dasar termasuk item yang nyata, kegiatan, atau hak istimewa yang menurut definisi yang diinginkan oleh anak.

4. Rutinitas sehari-hari

Goodnow (dalam Bornstein:2002) menekankan pentingnya rutinitas sehari-hari sebagai sumber informasi tentang nilai-nilai. Orang tua yang ingin di masih prinsip membantu orang lain, misalnya, bisa membuat pekerjaan sukarela bagian resmi dari kehidupan keluarga, atau mendaftarkan anak mereka dalam kelompok mana pekerjaan sukarela tersebut adalah bagian dari fungsi kelompok.

\section{Prearming}

Pre-arming adalah semua tentang komunikasi. Ketika anda melihat potensi

masalah, duduk dengan anak-anak Anda dan pastikan mereka tahu bagaimana Anda mengharapkan mereka untuk berperilaku dan mengapa. Kemudian menyediakan mereka dengan strategi yang dapat mereka gunakan ketika menghadapi seseorang atau sesuatu yang bertentangan apa yang anda miliki dengn apa yang anda ajarkan kepada mereka. Misalnya, Anda bisa mengatakan anak Anda untuk mematikan komputer jika terjadi sesuatu yang mereka tidak seharusnya lihat. (Tandberg:2009)

\section{Sistem Dasar Pekerjaan Sosial}

Mengutip dari Edi Suharto (1997 : 319 : 320), Pincus dan Minahan membagi sistem dasar pekerjaan sosial ke dalam 4 jenis, yaitu :

a. Sistem pelaksana perubahan : sekelompok orang yang tugasnya memberi bantuan atas dasar keahlian yang berbeda-beda dan bekerja dengan sistem yang berbeda-beda pula ukurannya. Seorang pekerja sosial disebut sebagai sistem pelaksana perubahan.

b. Sistem klien : dapat merupakan individu, kelompok, keluarga, organisasi atau masyarakat yang meminta bantuan atau pelayanann kepada sistem pelaksana perubahan.

c. Sistem sasaran : pihak-pihak yang dapat dijadikan sasaran perubahan atau dijadikan media yang dapat mempengaruhi proses pencapaian tujuan pertolongan.

d. Sistem kegiatan : menunjuk pada orangorang yang bekerja sama dengan pekerja sosial untuk melakukan usaha-usaha perubahan melalui pelaksanaan tugastugas atau program kerja.

\section{Sumber -Sumber Kesejahteraan Sosial}

Menurut (Wibhawa dkk:2010:29), Kehidupan manusia memiliki beragam kebutuhan yang mesti dipenuhi agar mereka dapat hidp fungsional, kehidupan yang memuaskan. Kebutuhan-kebutuhan itu terdiri dari tempat, tinggal, perawatan kesehatan, keamanan, 
kesempatan untuk tumbuh kembang secara emosional dan intelektual, hubungan dengan lainnya, dan pemenuhan kebutuhan spritual. Biasanya, beberapa kebutuhan tersebut dapat dipenuhi melalui sumber-sumber personal, atau dalam keluarga dan jaringan pertemanan. Tetapi ketika sumber-sumber personal tidak sesuai (tidak diperoleh), kebutuhan-kebutuhan tersebut harus dipenuhi melalui mekanisme pemenuhan kebutuhan-kebutuhan tersebut.

\section{Kebutuhan sumber-sumber}

Dalam masyarakat kontemporer mekanisme yang digunakan untuk memenuhi kebutuhan manusia dapat dikategorikan sebagai berikut:

- Personal: diri, sendiri, keluarga, teman, kolega kerja

- Informal: Penolong alami dalam masyarakat, kelompok kemandirian ( self-help groups), klub, dan kelompok lainnya yang berfungsi secara informal

- Instutional: Sekolah, rumah sakit, dan organisasi formal lainnya

- Kemasyarakatan: Pelayanan, badanbadan, dan lembaga-lembaga yang disiapkan untuk memenuhi kebutuhan khusus masyarakat tertentu

\section{Rentang sumber}

Suatu rentang pelayanan dan sumber yang banyak adalah dibutuhkan bagieseorang atau keluarga untuk memperoleh level keberfungsian social yang optimal dalam masyarakat Indonesia. Perubahan kebutuhankebutuhan khusus dari waktu ke waktu dari suatu masyarakat ke masyarakat lainya tergantung pada luasnya rentang lingkupnya. Rentang kebutuhan terdiri dari:

Parenting: wilayah ini terdiri dari konseling orang tua dan anak-anak; pelayanan dukungan bagi orang tua anak-anak dengan kebutuhan khusus atau bagi orang tua yang tidak mampu untuk melakukan peran orang tua secara mandiri; pelayanan pendidikan di fokuskan pada peran orang tua; dan perawatan pengganti anak (day care atau faster care) bagi anak-anak yang membutuhkan secara paruh waktu atau penuh waktu diluar seting perawatan keluarga.

Keterkaitan antara Pengetahuan Pengasuhan, Parenting Education dan Teknik Parenting.

Orang tua sebagai figur yang memegang peran penting dalam proses pengasuhan dituntut untuk terus mendukung dalam memelihara pertumbuhan anak tidak hanya secara fisik namun yang terpenting juga membentuk kelekatan emosional dan ikatan psikologis dengan anak (Brooks, 2001 dalam Meliala). Penting bagi orang tua menggunakan pola pengasuhan yang tepat, sebab cara orang tua mengasuh anak akan sangat berhubungan dengan bagaimana perasaan anak tentang dirinya dan bagaimana anak berelasi dengan orang lain. (Martin\&Colbert,1997 dalam Meliala). Sehingga, orang tua memerlukan pemahaman dan keterampilan cukup dan tepat mengenai pengasuhan anak.

Pengetahuan pengasuhan meliputi memahami cara merawat anak-anak, bagaimana anakanak mengembangkan, dan peran yang beragam orang tua bermain dalam kehidupan anak-anak. Pengetahuan pengasuhan termasuk memahami berbagai pendekatan yang tepat untuk memenuhi kebutuhan fisik dan biologis dan sosioemosional dan kognitif anak-anak ketika mereka berkembang (Goodnow \& Collins, $1990 \quad$ dalam William\&Lerner:2006:915). Pengetahuan yang memadai mengenai pengasuhan anak dapat berdampak baik bagi perkembangan anak. Namun, tidak semua orang tua memiliki latar belakang pengetahuan pengasuhan yang memadai untuk menunjang perkembangan anaknya. Orang tua memiliki pengetahuan mengenai pengasuhan berdasarkan pola pengasuhan yang mereka dapatkan ketika masa kecil. Serta faktor tingkat pendidikan dan status ekonomi pun berpengaruh terhadap kualitas pengetahuan orang tua mengenai pengasuhan anak. 
Orang tua dapat memperluas pengetahuan dan keterampilan dalam pengasuhan anak memlaui program-program Parenting Education. Parenting Education (Pendidkan Parenting) adalah pendidikan yang berupaya untuk meningkatkan atau memfasilitasi perilaku orang tua yang akan mempengaruhi hasil positif perkembangan pada anak-anak mereka (Bornstein Vol IV:2002:434).

Pada dewasa ini, banyak lembaga formal dan non formal yang memberikan pelayanan sosial berupa Program parenting education. Parenting Education dapat menjadi suatu sistem sumber bagi orang tua yang ingin memperluas wawasan dan melatih keterampilan dalam mengasuh anak.

Parenting education ini biasanya diberikan oleh sebuah lembaga pendidikan formal dan non formal dengan fokus target, jenis-jenis, metode-metode penyampaian parenting education yang berbeda-beda. Metode penyampaian parenting education termasuk buku pegangan dan manual; televisi, video, dan seri audio; kelas pengasuhan dan perkembangan anak berbasisb kelompok, program kunjungan rumah; dan kombinasi di atas. Setiap orang tua pasti memiliki tantangan yang berbeda dalam mengasuh anak-anak mereka. Tantangan dalam pengasuhan tersebut yang menjadi landasan mengapa program parenting education memiliki beragam jenis, fokus target, dan metode penyampaian. Orang tua dapat mengikuti program parenting education yang paling sesuai untuk membantu menyelesaikan masalah dalam pengasuhan anak. Pengasuhan yang kurang baik dapat terjadi untuk alasan yang berbeda dan akan terwujud dalam berbagai cara. Belajar keterampilan orangtua yang baik akan membantu anak-anak lebih bahagia dan memiliki kesempatan sukses yang lebih besar dalam

(http://www.livestrong.com/article/170923lack-of-parenting-skills/).
Istilah Parenting secara umum diartikan sebagai pengasuhan meskipun arti dari parenting sendiri lebih luas. Menurut (Martin \& Colbert:1997 dalam Meliala:2012), Parenting merupakan serangkaian interaksi berkelanjutan antara orang tua dan anak, yaitu proses yang menyebabkan perubahan kedua belah pihak. Menurut definisi, proses ini melibatkan proses melahirkan, melindungi, mengasuh, dan membimbing anak-anak. Parenting sebagai suatu proses yang kompleks turut dipengaruhi oleh berbagai faktor baik dari sisi orang tua dan anak. Pada orang tua faktor-faktor yang berpengaruh dalam proses parenting adalah kepribadian, beliefs, pengetahuan, gender, dan sejarah perkembangan atau masa kecil mereka. Sedangkan pada anak, faktor-faktor yang berpengaruh dalam proses parenting adalah temperamen, gender, kemampuan dan usia anak.

Parenting education memiliki banyak jenis, fokus target, dan metode penyampaian. Namun, konten dalam program parenting education selalu mengajarkan dan melatihkan suatu teknik parenting yang dapat diterapkan dalam mengasuh anak.

Ada penelitian yang cukup tentang berbagai teknik yang orang tua mempekerjakan dalam perjalanan bersosialisasi kepada anak-anak mereka. Ada juga sejumlah besar ditujukan kepada masalah gaya pengasuhan dan dampaknya terhadap perilaku anak-anak. Sebuah signifikan tidak bisa kesimpulan yang muncul dari penelitian ini adalah bahwa efek dari teknik parenting dan gaya tergantung pada banyak fitur yang besar dari anak dan situasi di mana orang tua dan anak sendiri. Penelitian modern jelas menunjukkan bahwa pembicaraan dari dampak teknik parenting dan gaya menyesatkan kecuali satu memperhitungkan berbagai variabel yang terkait dengan anak dan dengan situasi. Setelah menjelaskan penelitian umum tentang teknik dan gaya, bagian ini karena akan fokus pada variabel yang spesifik 
yang mempengaruhi hasil dari teknik yang berbeda dan gaya (Bornstein Vol.5:2002:156)

Teknik Parenting mencakup orangorang yang bekerja dalam menanggapi tindakan anak dan orang-orang yang terjadi independen dari tindakan anak dalam upaya untuk memfasilitasi perilaku yang dapat diterima secara sosial. Teknik Parenting yang dikemukakan Grusec (dalam Bornstein:2002:154) yaitu : 1.) Disiplin; 2)Monitoringataupemantauan;3)Rewardatau penghargaan; 4) Rutinitas Sehari-hari ;5) Prearming

Secara umum, teknik parenting yang dikemukakan Grusec diatas merupakan teknikteknik yang biasa diterapkan dalam pengasuhan anak. Pertama adalah teknik disiplin. Setiap orang tua mengajarkan perilaku disiplin kepada anak-anaknya. Namun, karakter anak-anak dan orang tua berbeda-beda sehingga setiap orang tua mungkin menerapkan teknik disiplin yang berbeda-beda dan dianggap paling efektif untuk menumbuhkan perilaku disiplin anak. Kedua, teknik monitoring atau pemantauan. Teknik ini dipakai orang tua untuk mengetahui kegiatan apa yang dilakukan anak, bagaimana kondisi anak, dan dampaknya kepada anak. Teknik monitoring ini diterapkan orang tua dari sejak anak lahir bahkan sampai anak beranjak dewasa. Ketiga, Reward atau penghargaan. Teknik ini diterapkan oleh orang tua yang memberi penghargaan apabila anak patuh dan melakukan suatu perilaku yang positif. Keempat, rutinitas sehari-hari. Teknik ini diterapkan orang tua dengan memberikan suatu tugas yang dilakukan sehari-hari seperti membantu mencuci piring, menyapu, merapikan tempat tidur dll. Teknik ini bertujuan untuk menumbuhkan sikap mandiri dan rajin pada anak. Kelima, prearming adalah teknik yang diterapkan oleh orang tua dalam hal berkomunikasi. Orang tua mengkomunikasikan kepada anak ap yang baik untuk mereka lakukan dan apa yang tidak baik atau dilarang untuk dilakukan serta menjelaskan apa alasannya.

Teknik-teknik parenting tersebut tentu perlu disesuaikan dengan karakter dan kondisi anak. Orang tua yang mempersiapkan dan membekali dirinya dengan pengetahuan yang memadai mengenai pengasuhan dan memahami karakter anak mereka dapat menerapkan teknik parenting yang tepat dan sesuai dalam mengasuh anak mereka.

\section{KESIMPULAN}

Pengetahuan pengasuhan anak sebaiknya dimiliki oleh orang tua agar dapat mengasuh anak lebih baik dan menunjang pertumbuhan dan perkembangan anak. Namun, pada kenyataanya tidak semua orang tua memiliki pengetahuan dan keterampilan yang memadai mengenai pengasuhan anak. Minimnya pengetahuan dan keterampilan orang tua mengenai pengasuhan dapat menimbulkan perlakuan salah pada anak. Pengasuhan oleh orang tua dipengaruhi oleh beberapa faktor seperti lingkungan sosial dan fisik tempat dimana keluarga itu tinggal, status ekonomi orang tua, dan model pengasuhan yang didapatkan orang tua sebelumnya.

Orang tua dapat memperluas pengetahuan dan keterampilan dalam pengasuhan anak memlaui program-program Parenting Education. Parenting Education (Pendidkan Parenting) adalah pendidikan yang berupaya untuk meningkatkan atau memfasilitasi perilaku orang tua yang akan mempengaruhi hasil positif perkembangan pada anak-anak mereka (Bornstein Vol IV:2002:434). Parenting education menjelaskan berbagai program pengajaran dan dukungan yang fokus pada keterampilan, perasaan, dan tugas menjadi orangtua (Einzig, 1996, hal. 222 dalam Bornstein Vol IV:2002:391). Parenting education ini biasanya diberikan oleh sebuah lembaga pendidikan formal dan non formal dengan fokus target, jenis-jenis, metodemetode penyampaian parenting education yang berbeda-beda. 
Penerapan Teknik parenting dapat menjadi metode atau cara untuk membantu orang tua dapat mengasuh anaknya lebih baik. Teknik Parenting merupakan mencakup orang-orang yang bekerja dalam menanggapi tindakan anak dan orang-orang yang terjadi independen dari tindakan anak dalam upaya untuk memfasilitasi perilaku yang dapat diterima secara sosial. Apabila dikaitkan dengan konsep pekerjaan sosial, lembaga yang memberikan pelayanan parenting education merupakan sistem sumber bagi klien yang memiliki masalah mengenai pengasuhan anak.

Berdasarkan penjabaran sebelumnya, kurangnya pengetahuan dan keterampilan orang tua mengenai pengasuhan dapat menimbulkan perlakuan salah pada anak dapat dicegah dan diminimalisir serta pemenuhan kebutuhan pada anak dapat terpenuhi apabila orang tua mendapatkan penambahan pengetahuan dan keterampilan pengasuhan melalui program parenting education sehingga orang tua dapat menerapkan teknik atau cara mengasuh anak yang benar.

\section{DAFTAR PUSTAKA}

Agustiawati, Isni. 2014. Skripsi :2014 Pengaruh Pola Asuh Orangtua terhadap Prestasi belajar siswa pada mata pelajaran Akuntansi kelas XI IPS di SMA Negeri 26 Bandung Universitas Pendidikan Indonesia | repository.upi.edu.
Bornstein, Marc.2002. Handbook of Parenting Second Edition

Volume 1-5 Practical Issues in Parenting. London

Meliala. Dianisa Gyanina.2012.Skripsi: Parenting Self-Efficiacy pada Ibu dengan Anak Usia Kanak-kanak Madya Ditinjau dari Attachment yang dimiliki di Masa Lalu. Depok:Universitas Indonesia

O'Connor, Thomas G and Scott, Stephen B.C. 2007.Parenting and outcomes for children. New York: Joseph Rowntree Foundation

Sackett, Jason. 2003,2007. Parenting Tools for Kids 1-12. LCSW USC Center for Work and Family Life.

Tandberg, Kari.2009.Parenting Matters: Strategies for Countering Media Influences. CFERT Colorado State University Department of Psychology

Wibawa, Budhi. Raharjo, Santoso T. Budiarti S, Meilany. 2010. Dasar-Dasar Pekerjaan Sosial. Bandung : Widya Padjadjaran.

http://www.livestrong.com/article/269193the-effects-of-verbal-encouragementon-children/ ( Minggu, 3 mei 2015, $22.00 \mathrm{wib})$

(http://www.livestrong.com/article/170923lack-of-parenting-skills/ 